\title{
PENYIMPANAN OBAT DI GUDANG INSTALASI FARMASI RS PKU MUHAMMADIYAH YOGYAKARTA UNIT I
}

\author{
Baby Sheina, M.R. Umam, Solikhah \\ Fakultas Kesehatan Masyarakat, Universitas Ahmad Dahlan, Yogyakarta
}

\begin{abstract}
Background: Medicine arrangement in Hospital Pharmaceutical Installation included planning, procurement, distribution, and utilizing. Medicine storage indicator was : the suitability between goods and stock card, TOR (Turn Over Ratio), percentage of medicine which was expired and or damaged, storage room arrangement system, percentage of dead stock, and percentage of final stock value. Based on the result of work evaluation of Pharmaceutical Supply Inventory for tablet supply in Pharmaceutical Installation Storage Room at PKU Muhammadiyah Yogyakarta Hospital Unit I, it was found that unsuitability between goods quantity with stock card and computerization was as much as 15,38 \%, TOR value was 29 times every year, final sock value was $6 \%$, medicine percentage was ED (expired date) $0,03 \%$. This data showed us that the suitability between goods and stock care, medicine ED percentage, TOR, and final stock value didn't meet the hospital target yet.

Method: This research was a kind of qualitative description with a draft as observational research. The subjects at this research were The Head of Pharmaceutical Installation, The Head of Pharmaceutical Installation Storage Room, officers of Pharmaceutical Installation Storage Room, and The Head of Maintenance Unit. The means of the research used observatory method and a deep interview. Data analysis was made in a way of qualitative description, and triangulation technique was done to guarantee data validity.

Results: Based on the result of research by using observation and deep interview, we knew that medicine storage system in Pharmaceutical Installation Storage Room didn't meet the standard because the medicine arrangement didn't refer to therapy class/ medicine merit. The building and the rooms were suitable with the standard, but the equipments didn't meet the standard because there was no alarm, gram and milligram measurement, box opener, and maintenance card. Human resource was already suitable with the standard because there were Pharmacist and the assistant available.

Conclusion: The factor of medicine and equipment stock room system was not suitable with the standard, but the factor of building, rooms and human resource in Pharmaceutical Installation Storage Room at PKU Muhammadiyah Yogyakarta Hospital Unit I were already suitable with the standard.
\end{abstract}

Keywords: Medicine storage, Building and Rooms, Equipment, Human Resource.

\section{PENDAHULUAN}

Kesehatan merupakan hak asasi manusia. Setiap orang mempunyai hak untuk hidup layak, baik menyangkut kesehatan pribadi maupun keluarganya termasuk di dalamnya mendapat makanan, pakaian, dan pelayanan kesehatan serta pelayanan sosial lain yang diperlukan. ${ }^{1}$

Upaya kesehatan bertujuan untuk memelihara dan meningkatkan kesehatan dan tempat yang digunakan untuk menyelenggarakannya disebut sarana kesehatan. Sarana kesehatan berfungsi untuk melakukan upaya kesehatan dasar atau upaya kesehatan rujukan dan/atau upaya kesehatan penunjang. Selain itu, sarana kesehatan dapat juga dipergunakan untuk kepentingan pendidikan dan pelatihan serta penelitian, pengembangan ilmu pengetahuan dan teknologi di bidang kesehatan. Salah satu sarana kesehatan yang menyelenggarakan upaya kesehatan adalah rumah sakit. ${ }^{1}$ 
Rumah sakit dengan organisasi di dalamnya harus dikelola dengan sebaikbaiknya, agar dapat memberikan pelayanan kesehatan semaksimal mungkin kepada masyarakat, sehingga tercapai tujuan terciptanya derajat kesehatan yang optimal. Salah satu diantaranya adalah pengelolaan obat di Instalasi Farmasi Rumah Sakit (IFRS), meliputi: perencanaan, pengadaan, penyimpanan, distribusi dan penggunaan obat. IFRS merupakan bagian dari unit pelayanan penunjang medik yang sangat penting di rumah sakit karena memberikan pelayanan obat serta bahan dan alat kesehatan habis pakai dari kebutuhan rumah sakit. Selain itu merupakan unit yang paling banyak menggunakan anggaran untuk pengadaan obat. Di lain pihak IFRS merupakan sumber penerimaan bagi rumah sakit. ${ }^{1}$

Rumah Sakit PKU Muhammadiyah Yogyakarta merupakan rumah sakit tipe C plus yang status kepemilikannya adalah Yayasan Muhammadiyah. Instalasi Farmasi Rumah Sakit (IFRS) merupakan bagian integral dari pelayanan kesehatan di RS PKU Muhammadiyah Yogyakarta dan berfungsi memberikan pelayanan kefarmasian yang meliputi perencanaan, penyediaan, dan distribusi semua perbekalan farmasi, pelayanan kefarmasian, memberikan informasi dan menjamin kualitas seluruh pelayanan yang menjadi tanggung jawab farmasi sampai ke permasalahan penggunaan obat serta penelitian dan pengembangan.

Indikator penyimpanan obat yaitu: 1) Kecocokan antara barang dan kartu stok, indikator ini digunakan untuk mengetahui ketelitian petugas gudang dan mempermudah dalam pengecekan obat, membantu dalam perencanaan dan pengadaan obat sehingga tidak menyebabkan terjadinya akumulasi obat dan kekosongan obat, 2) Turn Over Ratio, indikator ini digunakan untuk mengetahui kecepatan perputaran obat, yaitu seberapa cepat obat dibeli, didistribusi, sampai dipesan kembali, dengan demikian nilai TOR akan berpengaruh pada ketersediaan obat. TOR yang tinggi berarti mempunyai pengendalian persediaan yang baik, demikian pula sebaliknya, sehingga biaya penyimpanan akan menjadi minimal, 3) Persentase obat yang sampai kadaluwarsa dan atau rusak, indikator ini digunakan untuk menilai kerugian rumah sakit, 4) Sistem penataan gudang, indikator ini dígunakan untuk menilai sistem penataan gudang standar adalah FIFO dan FEFO, 5) Persentase stok mati, stok mati merupakan istilah yang digunakan untuk menunjukkan (item persediaan obat di gudang yang tidak mengalami transaksi dalam waktu minimal 3 bulan, 6) Persentase nilai stok akhir, nilai stok akhir adalah nilai yang menunjukkan berapa besar persentase jumlah barang yang tersisa pada periode tertentu, nilai persentese stok akhir berbanding terbalik dengan nilai TOR. ${ }^{1}$

Menurut Surat Keputusan Direksi Rumah Sakit PKU Muhammadiyah Yogyakarta No 1900/E-IV/SK.3.2/06/08 tentang Pedoman Pelayanan Farmasi Rumah Sakit PKU Muhammadiyah Yogyakarta untuk target presisi (kecocokan) data stok dilogistik farmasi $\geq 90 \%$, hal ini berarti tingkat ketidaksesuaian antara barang di gudang dengan kartu stok dan komputer harus $\leq 10 \%$, target persentase obat expired date (ED) sebesar $0 \%$, target turn over ratio (TOR) gudang farmasi $\geq 36$ kali per tahun, target persentase stok akhir gudang farmasi $\leq 3 \%$, dan target persentase death stock (stok mati) $\leq 5 \%$.

Berdasarkan hasil evaluasi kinerja dari inventory perbekalan farmasi untuk sediaan tablet di Gudang Instalasi Farmasi RS PKU Muhammadiyah Yogyakarta Unit I triwulan I tahun 2009, didapatkan persentase ketidaksesuaian jumlah obat yang ada di gudang dengan kartu stok dan komputer sebesar 15,38\%, nilai TOR gudang farmasi 29 kali per tahun, nilai stok akhir gudang farmasi $6 \%$, persentase obat ED pada triwulan I tahun 2009 sebesar 0,03\%, hampir mendekati nilai $0 \%$ namun belum 0\% sehingga dapat diartikan masih ditemukannya obat ED pada triwulan I tahun 2009. Hal ini menunjukkan bahwa presisi data stok, persentase obat ED, nilai TOR, dan nilai stok akhir tahun belum memenuhi target rumah sakit. Persentase stok mati sebesar $2,18 \%$ menunjukkan bahwa persentase stok mati telah mencapai target yang diharapkan namun akan lebih baik jika diminimalkan jumlahnya. 
Pengelolaan obat oleh Instalasi Farmasi Rumah Sakit (IFRS) mempunyai peran penting dalam pelaksanaan pelayanan kesehatan di rumah sakit, oleh karena itu pengelolaan obat yang kurang efisien pada tahap penyimpanan akan berpengaruh terhadap peran rumah sakit secara keseluruhan.

Penelitian ini bertujuan untuk mengetahui gambaran penyimpanan obat di Gudang Instalasi Farmasi RS PKU Muhammadiyah Yogyakarta Unit I.

\section{METODE PENELITIAN}

Penelitian ini merupakan jenis penelitian deskriptif kualitatif dengan rancangan sebagai penelitian observasional. Penelitian ini dilakukan di Gudang Instalasi Farmasi RS PKU Muhammadiyah Yogyakarta Unit I. Subyek penelitian yaitu Kepala Instalasi Farmasi, Kepala Gudang Instalasi Farmasi, Petugas Gudang Instalasi Farmasi, dan Kepala Bagian Pemeliharaan. Alat penelitian menggunakan metode observasi dan wawancara mendalam. Analisis data dilakukan secara deskriptif kualitatif dan untuk menjamin validitas data dilakukan teknik triangulasi.

\section{HASIL PENELITIAN DAN PEMBAHASAN}

\section{a. Faktor Sistem Penyimpanan Obat di Gudang Instalasi Farmasi Rumah Sakit}

Sistem penyimpanan obat di Gudang Instalasi Farmasi menggunakan gabungan antara metode FIFO dan metode FEFO. Metode FIFO (First in First Out), yaitu obat-obatan yang baru masuk diletakkan di belakang obat yang terdahulu, sedangkan metode FEFO (first expired first out) dengan cara menempatkan obat-obatan yang mempunyai ED (expired date) lebih lama diletakkan di belakang obat-obatan yang mempunyai ED lebih pendek. Proses penyimpanannya memprioritaskan metode FEFO, baru kemudian dilakukan metode FIFO. Barang yang ED-nya paling dekat diletakkan di depan walaupun barang tersebut datangnya belakangan. Sistem penyimpanan dikelompokkan berdasarkan jenis dan macam sediaan, yaitu:

1). Bentuk sediaan obat (tablet, kapsul, sirup, drop, salep/krim, injeksi dan infus).

2). Bahan baku.

3). Nutrisi.

4). Alat-alat kesehatan.

5). Gas medik.

6). Bahan mudah terbakar.

7). Bahan berbahaya.

8). Reagensia.

9). Film Rontgen.

Penyusunan obat pada Gudang Instalasi Farmasi di RS PKU Muhammadiyah Yogyakarta Unit I sudah berdasarkan abjad/alphabetis dari A-Z, tetapi penyusunannya belum dilaksanakan berdasarkan kelas terapi/khasiat obat.

Penyimpanan obat di gudang diawali dari menerima barang dan dokumendokumen pendukungnya, memeriksa barang, pengarsipan, memasukkan datadata ke komputer, setelah itu proses menyimpan barang di ruang penyimpanan.

Kesesuaian antara sistem penyimpanan obat di Gudang Instalasi Farmasi RS PKU Muhammadiyah Yogyakarta Unit I dengan standar Seto adalah sebagai berikut: 
Tabel 1. Kesesuaian Antara Sistem Penyimpanan Obat di Gudang Instalasi Farmasi RS PKU Muhammadiyah Yogyakarta Unit I dengan Standar Seto ${ }^{5}$

\begin{tabular}{llc}
\hline \multirow{2}{*}{ Standar } & \multicolumn{2}{c}{$\begin{array}{l}\text { Pelaksanaan di Gudang Instalasi Farmasi } \\
\text { RS PKU Muhammadiyah Yogyakarta Unit I }\end{array}$} \\
\cline { 2 - 3 } Metode FIFO & Ya & Tidak \\
\hline Metode FEFO & $\sqrt{ }$ \\
\hline Penggolongan berdasarkan jenis dan macam sediaan & $\sqrt{ }$ \\
\hline Penggolongan berdasarkan abjad & $\sqrt{ }$ \\
\hline Penggolongan berdasarkan kelas terapi/khasiat obat & & $\sqrt{ }$
\end{tabular}

Sistem penyimpanan obat di Gudang Instalasi Farmasi RS PKU Muhammadiyah Yogyakarta Unit I tidak sesuai dengan standar Seto ${ }^{5}$, karena dalam sistem penyimpanan obatnya menggunakan metode FIFO dan FEFO, penggolongan obat berdasarkan jenis dan macam sediaan, dan penggolongan obat berdasarkan abjad/alphabetis, namun belum menerapkan penggolongan obat berdasar kelas terapi/khasiat obat.

Hambatan terkait dengan penyimpanan obat di Gudang Instalasi Farmasi RS PKU Muhammadiyah Yogyakarta Unit I antara lain adalah penggolongan obat yang belum berdasarkan kelas terapi/khasiat dikarenakan pola peresepan obat oleh dokter yang berubah-ubah. Hal tersebut dapat menyebabkan obat disimpan di gudang dalam yang waktu yang lama, sehingga resiko obat ED semakin besar. Hal tersebut dapat diatasi dengan cara:

1) Rumah sakit membentuk Clinical Leader, yaitu membentuk suatu perkumpulan yang terdiri dari para dokter yang dipimpin oleh para dokter spesialis yang profesional untuk merumuskan suatu standar obat/formularium untuk penyakit yang sedang trend saat ini yang kemudian direkomendasikan ke PFT (Panitia Farmasi dan Terapi).

2) PFT mengembangkan, merevisi, mengubah, dan menetapkan formularium berdasarkan rekomendasi Clinical Leader.

3) PFT menetapkan program dan prosedur yang membantu memastikan terapi obat yang aman dan bermanfaat.

Seorang dokter harus memiliki cukup pengetahuan dasar mengenai ilmuilmu farmakologi yaitu tentang farmakodinamik, farmakokinetik, dan sifat-sifat fisiko kimia obat yang diberikan dapat menuliskan resep yang tepat dan rasional. Oleh karena itu dokter memainkan peranan penting dalam proses pelayanan kesehatan khususnya dalam melaksanakan pengobatan melalui pemberian obat kepada pasien. $^{2}$

Instalasi Farmasi Rumah Sakit (IFRS) mempunyai berbagai fungsi, yang dapat digolongkan menjadi fungsi nonklinik dan fungsi klinik. Lingkup fungsi farmasi klinik mencakup fungsi farmasi yang dilakukan dalam program rumah sakit, yaitu: pemantauan terapi obat (PTO); evaluasi penggunaan obat (EPO); penanganan bahan sitotoksik; pelayanan di unit perawatan kritis; pemeliharaan formularium; penelitian; pengendalian infeksi di rumah sakit; sentra informasi obat; pemantauan dan pelaporan reaksi obat merugikan (ROM); sistem formularium, panitia farmasi dan terapi; sistem pemantauan kesalahan obat; bulletin terapi obat; program edukasi "in-service" bagi apoteker, dokter, dan perawat; investigasi obat; dan unit gawat darurat. Lingkup farmasi nonklinik adalah perencanaan; penetapan spesifikasi produk dan pemasok; pengadaan; pembelian; produksi; penyimpanan; 
pengemasan dan pengemasan kembali; distribusi; dan pengendalian semua perbekalan kesehatan yang beredar dan digunakan secara keseluruhan. ${ }^{2}$

Panitia Farmasi dan Terapi (PFT) didefinisikan sebagai suatu badan penasihat dan pelayanan melalui garis organisatoris yang berfungsi sebagai penghubung antara staf medis dan bagian/instalasi farmasi. Komite ini anggotanya terdiir dari para dokter, farmasis, para staf medis/kesehatan PFT berwenang sepenuhnya melaksanakan sistem formularium, merumuskan dan mengendalikan pelaksanaan semua kebijakan, ketetapan, prosedur, aturan yang berkaitan dengan obat. Panitia ini juga mempunyai wewenang penuh mengadakan, mengembangkan, menetapkan, merevisi dan mengubah formularium, dan menyetujui perubahan kebijakan penggunaan obat dan pelayanan IFRS. ${ }^{5}$

Hasil utama dari pelaksanaan sistem formularium adalah formularium rumah sakit. Formularium adalah dokumen berisi kumpulan produk obat yang dipilih PFT disertai informasi tambahan penting tentang penggunaan obat tersebut, serta kebijakan dan prosedur berkaitan obat yang relevan untuk rumah sakit tersebut, yang terus-menerus direvisi agar selalu akomodatif bagi kepentingan penderita dan staf profesional pelayan kesehatan, berdasarkan data konsumtif dan data morbiditas serta pertimbangan klinik staf medik rumah sakit itu. Salah satu karakteristik penting dalam suatu sistem formularium ialah bahwa sistem itu mencerminkan pertimbangan klinik mutakhir dari staf medik rumah sakit, tempat sistem itu diterapkan. ${ }^{2}$

Penelitian yang dilakukan di Instalasi Farmasi Rumah Sakit Pandan Arang Boyolali, didapatkan hasil bahwa penyusunan obat di Instalasi Farmasi Rumah Sakit Pandan Arang Boyolali berdasarkan nama generik alfabetis dan FIFO/First in First Out (obat yang pertama datang dikeluarkan lebih dahulu). Penyimpanan obat telah berjalan dengan baik, rapi, dan tidak ada obat yang kadaluarsa. ${ }^{2}$

\section{b. Faktor Gedung dan Ruangan di Gudang Instalasi Farmasi Rumah Sakit}

Lokasi Gudang Instalasi Farmasi RS PKU Muhammadiyah Yogyakarta Unit I terletak dekat dengan jalan raya, sehingga mudah dijangkau oleh kendaraan angkut barang dan memudahkan proses pengiriman barang dari para distributor obat. Letak Gudang Instalasi farmasi menyatu dengan sistem pelayanan di rumah sakit. menjadi:

Gudang Instalasi Farmasi RS PKU Muhammadiyah Yogyakarta dibagi

1) Ruang Produksi

2) Ruang Kantor

3) Ruang Arsip Dokumen

4) Ruang Penyimpanan

Ruang penyimpanan Gudang Instalasi Farmasi RS PKU Muhammadiyah Yogyakarta Unit I terdiri dari:

1) Ruang obat jadi

2) Ruang obat produksi

3) Ruang untuk bahan baku obat

4) Ruang untuk alat kesehatan

5) Ruang untuk obat termolabil kesehatan

6) Ruang alat kesehatan dengan suhu rendah

7) Ruang untuk obat mudah terbakar

8) Ruang untuk obat berbahaya 
Ruang penyimpanan terdapat pengaturan suhu dan kelembaban yang dilakukan secara berkala, yaitu 2 (dua) kali sehari setiap jam 08.00 WIB dan 16.00 WIB.

Kesesuaian antara gedung dan ruangan di Gudang Instalasi Farmasi RS PKU Muhammadiyah Yogyakarta Unit I dengan Standar Pelayanan Farmasi di Rumah Sakit adalah sebagai berikut:

Tabel 2. Kesesuaian Antara Gedung dan Ruangan di Gudang Instalasi Farmasi RS PKU Muhammadiyah Yogyakarta Unit I dengan Standar Pelayanan Farmasi di Rumah Sakit ${ }^{2}$

\begin{tabular}{|c|c|c|}
\hline \multirow[t]{2}{*}{ Standar Pelayanan Farmasi di Rumah Sakit } & \multicolumn{2}{|c|}{$\begin{array}{l}\text { Pelaksanaan di Gudang In- } \\
\text { stalasi Farmasi RS PKU Mu- } \\
\text { hammadiyah Yogyakarta Unit I }\end{array}$} \\
\hline & $\mathrm{Ya}$ & Tidak \\
\hline Lokasi menyatu dengan sistem pelayanan rumah sakit. & $\sqrt{ }$ & \\
\hline Luas yang cukup & $\sqrt{ }$ & \\
\hline $\begin{array}{l}\text { Dipisahkan antara fasilitas penyelenggaraan manajemen, pelayanan langsung pada } \\
\text { pasien, dispensing, serta pembuangan limbah. }\end{array}$ & $\sqrt{ }$ & \\
\hline Dipisahkan antara jalur steril, bersih, daerah abu-abu, serta daerah bebas kontaminasi. & $\sqrt{ }$ & \\
\hline Adanya pengaturan suhu. & $\sqrt{ }$ & \\
\hline Adanya pengaturan sinar. & $\sqrt{ }$ & \\
\hline Adanya pengaturan kelembaban. & $\sqrt{ }$ & \\
\hline Terdapat ruang kantor. & $\sqrt{ }$ & \\
\hline Terdapat ruang produksi. & $\sqrt{ }$ & \\
\hline Terdapat ruang penyimpanan. & $\sqrt{ }$ & \\
\hline Terdapat ruang obat jadi & $\sqrt{ }$ & \\
\hline Terdapat ruang obat produksi. & $\sqrt{ }$ & \\
\hline Terdapat ruang bahan baku obat. & $\sqrt{ }$ & \\
\hline Terdapat ruang alat kesehatan. & $\sqrt{ }$ & \\
\hline Terdapat ruang obat termolabil. & $\sqrt{ }$ & \\
\hline Terdapat ruang alat kesehatan dengan suhu rendah. & $\sqrt{ }$ & \\
\hline Terdapat ruang obat mudah terbakar. & $\sqrt{ }$ & \\
\hline Terdapat ruang obat/bahan obat berbahaya. & $\sqrt{ }$ & \\
\hline Terdapat ruang arsip dokumen & $\sqrt{ }$ & \\
\hline
\end{tabular}

Gedung dan ruangan Gudang Instalasi Farmasi RS PKU Muhammadiyah Unit I sudah sesuai dengan Standar Pelayanan Farmasi di Rumah Sakit. ${ }^{8}$

Hambatan dari aspek gedung dan ruangan Gudang Instalasi Farmasi RS PKU Muhammadiyah Yogyakarta Unit I yaitu jarak gudang yang jauh dari Pelayanan Rawat Inap, serta luas gudang yang kurang memadai. Hal tersebut dapat diatasi dengan cara:

1) Membuat satelit gudang farmasi yang ditempatkan di setiap bangsal perawatan. Gudang utama berfungsi sebagai Safety Stock, sedangkan satelit digunakan untuk mempermudah permintaan dan pengiriman obat antara gudang utama dan bangsal perawatan.

2) Menerapkan model Computerize Inventory, yaitu lemari inventory/logistik yang dilengkapi dengan sistem komputerisasi, menggunakan password yang dapat diakses tiap satelit di bangsal untuk mempermudah permintaan obat ke gudang utama.

Menurut Seto ${ }^{5}$,Gudang Farmasi adalah awal dari penyimpanan perbekalan farmasi yang datang dari supplier, perbekalan farmasi tersebut kemudian didistribusikan ke bagian rawat inap, rawat jalan, dan unit-unit pelayanan rumah 
sakit yang membutuhkannya. Persyaratan gudang penyimpanan perbekalan farmasi:

1) Accesibility, adalah ruang penyimpanan harus mudah dan cepat diakses.

2) Size, ruang penyimpanan harus cukup untuk menampung barang yang ada.

Gudang Farmasi Rumah Sakit merupakan suatu bagian di rumah sakit yang kegiatannya dibawah manajemen departemen Instalasi Farmasi. Departemen Instalasi Farmasi dipimpin oleh seorang apoteker dan dibantu beberapa orang apoteker yang bertanggung jawab atas seluruh pekerjaan serta pelayanan kefarmasian yang mencakup pelayanan perencanaan, pengadaan, produksi, penyimpanan, perbekalan kesehatan atau persediaan farmasi, pengendalian mutu dan pengendalian distribusi penggunaan seluruh perbekalan kesehatan di rumah sakit. Gudang farmasi mempunyai fungsi sebagai tempat penyimpanan yang merupakan kegiatan dan usaha untuk mengelola barang persediaan farmasi yang dilakukan sedemikian rupa agar kualitas dapat diperhatikan, barang terhindar dari kerusakan fisik, pencarian barang mudah dan cepat, barang aman dari pencuridan mempermudah pengawasan stok. Gudang farmasi berperan sebagai jantung dari menjemen logistik karena sangat menetukan kelancaran dari pendistribusian. Oleh karena itu, maka metode pengendalian persediaan atau inventory control diperlukan, dipahami dan diketahui secara baik. ${ }^{2}$

Untuk mengembangkan manajemen institusi jasa Rumah Sakit maka perlu diadakan pengendalian sistem informasi yang memadai khususnya pada bagian Gudang Farmasi. Pengolahan data hendaknya dilakukan dengan cermat, cepat dan teratur. Penggunaan teknologi komputer didalam pengolahan data pada umumnya bertujuan untuk membantu memudahkan penyelesaian tugas manusia dalam pemrosesan data dan diharapkan dapat mengurangi kesalahan manusia. Data yang ada pada bagian Gudang Farmasi berupa data yang kompleks, data itupun diperlukan sewaktu-waktu. Untuk mendapatkan informasi yang diinginkan tentunya harus menggunakan sistem informasi. Sistem informasi dalam suatu organisasi dapat dikatakan sebagai suatu sistem yang menyediakan informasi bagi semua tingkatan dalam organisasi tersebut kapan saja diperlukan. Sistem ini menyimpan, mengambil, mengubah, mengolah dan mengkomunikasikan informasi yang diterima dengan menggunakan sistem informasi atau peralatan sistem lainnya sebagai suatu sistem di dalam suatu organisasi yang merupakan kombinasi dari orang-orang, fasilitas, teknologi, media prosedur-prosedur dan pengendalian yang ditujukan untuk mendapatkan jalur komunikasi penting, memproses tipe transaksi rutin tertentu, memberi sinyal kepada manajemen dan yang lainnya terhadap kejadian-kejadian internal dan eksternal yang penting dan menyediakan suatu dasar informasi untuk pengambilan keputusan. Dengan adanya komputer sebagai teknologi dalam penerapan sistem baru diharapkan mampu untuk meningkatkan produktifitas kerja para pegawai, guna memenuhi kebutuhan seperti :

1) Sistem dapat membantu dalam mencatat barang masuk maupun barang keluar dengan efektif.

2) Memudahkan dalam perubahan data yang ada.

3) Kebutuhan informasi dapat disajikan dengan cepat.

4) Pembuatan laporan yang dihasilkan lebih akurat.

Menurut Santoso, Sistem informasi Gudang Farmasi terdiri dari 9 modul:

1) Modul Pengguna, berisi grup dan daftar pengguna yang membatasi hak akses masing-masing pengguna. 
2) Modul Data Referensi, berisi manajemen data master seperti master obat, golongan obat, satuan, supplier, customer, dan sumber dana.

3) Modul Order Pembelian (Purchase Order), berisi manajemen order pembelian barang kepada supplier.

4) Modul Penerimaan, berisi manajemen penerimaan barang dari supplier, penerimaan dibagi 2 yaitu peneriman dengan PO (Purchase Order) atau penerimaan non-PO misal dari dana hibah atau lain-lain.

5) Modul Order distribusi, berisi manajemen order distribusi dari customer, dalam hal ini adalah Puskesmas dan Rumah Sakit di wilayah Kota Yogyakarta.

6) Modul Distribusi, berisi manajemen pendistribusian atau pengeluaran barang ke customer.

7) Modul Retur, berisi manajemen pengembalian barang karena rusak atau expired. Terdiri dari retur penerimaan (pengembalian ke supplier) dan retur distribusi (pengembalian dari customer).

8) Modul manajemen barang rusak, berisi manajemen barang rusak di gudang, untuk memisahkan barang yang rusak atau expired di gudang dengan barang yang masih baik.

9) Modul pelaporan, berisi output laporan dalam bentuk view html dan bisa dieksport ke format excel.

Penelitian yang dilakukan di Instalasi Farmasi Rumah Sakit Pandan Arang Boyolali, didapatkan hasil luas bangunan Instalasi Farmasi 123,5 $\mathrm{m}^{2}$. Pembagian ruangan terdiri dari ruang tunggu pasien, ruang administrasi, WC/KM, ruang Lysol/ alcohol, gudang obat I, gudang obat II, ruang distribusi obat rawat inap dan ruang distribusi rawat jalan merangkap ruang informasi. ${ }^{7}$

\section{c. Faktor Peralatan di Gudang Instalasi Farmasi Rumah Sakit}

Kesesuaian antara peralatan Gudang Instalasi Farmasi RS PKU Muhammadiyah Yogyakarta Unit। dengan Standar Pelayanan Farmasi di Rumah Sakit ${ }^{8}$ adalah sebagai berikut: 
Tabel 3. Kesesuaian Antara Peralatan Gudang Instalasi Farmasi RS PKU Muhammadiyah Yogyakarta Unit I dengan Standar Pelayanan Farmasi di Rumah Sakit. ${ }^{8}$

\begin{tabular}{|c|c|c|}
\hline \multirow[t]{2}{*}{$\begin{array}{l}\text { Standar Pelayanan Farmasi } \\
\text { di Rumah Sakit }\end{array}$} & \multicolumn{2}{|c|}{$\begin{array}{l}\text { Pelaksanaan di Gudang Instalasi Farmasi } \\
\text { RS PKU Muhammadiyah Yogyakarta Unit I }\end{array}$} \\
\hline & Ya & Tidak \\
\hline Peralatan untuk penyimpanan. & $\sqrt{ }$ & \\
\hline Peralatan untuk peracikan. & $\sqrt{ }$ & \\
\hline Peralatan untuk pembuatan & $\sqrt{ }$ & \\
\hline obat. & $\sqrt{ }$ & \\
\hline Meja. & $\sqrt{ }$ & \\
\hline Kursi. & $\sqrt{ }$ & \\
\hline Lemari buku/rak. & $\sqrt{ }$ & \\
\hline Filling cabinet. & $\sqrt{ }$ & \\
\hline Komputer. & $\sqrt{ }$ & \\
\hline Alat tulis kantor. & $\sqrt{ }$ & \\
\hline Telepon. & $\sqrt{ }$ & \\
\hline Kepustakaan. & $\sqrt{ }$ & \\
\hline Lemari penyimpanan khusus & $\sqrt{ }$ & \\
\hline untuk narkotika. & $\sqrt{ }$ & \\
\hline Lemari pendingin. & $\sqrt{ }$ & \\
\hline AC. & $\sqrt{ }$ & \\
\hline Penerangan. & $\sqrt{ }$ & \\
\hline Sarana air. & $\sqrt{ }$ & \\
\hline Ventilasi. & $\sqrt{ }$ & \\
\hline Sarana pembuangan limbah. & $\sqrt{ }$ & \\
\hline Alarm. & & $\sqrt{ }$ \\
\hline Lemari/rak. & $\sqrt{ }$ & \\
\hline Palet. & $\sqrt{ }$ & \\
\hline Kartu arsip. & $\sqrt{ }$ & \\
\hline Lemari arsip. & $\sqrt{ }$ & \\
\hline
\end{tabular}

Peralatan Gudang Instalasi Farmasi di RS PKU Muhammadiyah Unit I tidak sesuai dengan Standar Pelayanan Farmasi di Rumah Sakit ${ }^{8}$, karena tidak memiliki alarm, dikarenakan di dalam rumah sakit sudah terdapat alarm. Namun demikian alarm untuk gudang tetap diperlukan.

Pemeliharaan peralatan di seluruh instalasi/unit menjadi tanggung jawab Bagian Pemeliharaan. pemeliharaan peralatan pendukung farmasi di gudang belum dilakukan secara rutin. Pemeliharaan peralatan pendukung farmasi pada prakteknya hanya melakukan perbaikan alat-alat yang mengalami kerusakan. Formulir/dokumen yang berkaitan dengan pemeliharaan perlatan antara lain daftar jadwal pemeliharaan alat, formulir check list, formulir laporan alat rusak, dan kartu pemeliharaan. Peralatan pendukung farmasi yang rusak akan dicatat di buku Pencatatan Barang Rusak.

Hambatan dari aspek peralatan Gudang Instalasi Farmasi RS PKU Muhammadiyah Yogyakarta Unit I yaitu pemeliharaan peralatan pendukung farmasi di gudang belum dilakukan secara rutin. Hal tersebut dapat diatasi dengan cara melakukan pemeliharaan yang teratur baik dilakukan oleh petugas pemeliharaan maupun para petugas gudang itu sendiri. Melakukan pemeliharaan 
yang teratur akan menekan tingkat kerusakan alat, life time (waktu hidup) alat semakin tinggi, sehingga penghematan biaya dapat dilakukan.

Menurut Seto ${ }^{5}$, persyaratan ruang penyimpanan perbekalan farmasi:

1) Utilities, ruang penyimpanan memiliki sumber listrik, air, AC, dan sebagainya.

2) Communication, ruang penyimpanan harus memiliki alat komunikasi misalnya telepon.

3) Drainage, ruang penyimpanan harus berada di lingkungan yang baik dengan sistem pengairan yang baik pula.

4) Security, ruang penyimpanan harus aman dari resiko pencurian dan penyalahgunaan serta hewan pengganggu.

Memeriksa barang/obat secara berkala dan menjaga barang/obat dari kerusakan/hilang merupakan fungsi dari pemeliharaan dan pengendalian (controlling). Salah satu faktor yang perlu diperhatikan di dalam fungsi penyimpanan dan gudang adalah memelihara gedung dan peralatannya dengan sebaik mungkin. ${ }^{5}$

Kurang efisiennya penggunaan dan pemeliharaan sarana dan peralatan kesehatan juga diakibatkan karena kurang dilakukannya perencanaan pengadaan peralatan dan pemeliharaanya. Di beberapa negara kurang dari separuh peralatan yang ada tidak digunakan secara rutin. Karena lemahnya pengoperasian dan kurangnya kemampuan pemeliharaan serta tidak tersedianya biaya pemeliharaan (yang seharusnya di sediakan sekurangnya $1 \%$ dari nilai investasi peralatan tersebut), optimalnya biaya pemeliharaan adalah 7 - $8 \%$ dari biaya peralatan. Kurang baiknya pemeliharaan peralatan medik sering kali berakibat pada pendeknya masa pakai peralatan tersebut, dan berdampak pada meningkatnya tambahan biaya yang diperlukan untuk pemeliharaan mencapai $20 \%-40 \%$. Berkurangnya inventaris peralatan yang dapat digunakan meningkatkan biaya pelayanan hingga $60 \%-80 \%$.

Dalam Kepmenkes No. 004 tahun 2003 tentang kebijakan dan strategi desentralisasi bidang kesehatan disebutkan salah satu tujuan strategis adalah upaya penataan manajemen kesehatan di era desentralisasi. Salah satu langkah kunci dalam tujuan tersebut adalah mengembangkan sub sistem pemeliharaan dan optimalisasi pemanfaatan sarana dan alat kesehatan. Dan dalam langkah kunci Kepmenkes tersebut dinyatakan bahwa keberhasilan penyelenggaraan pelayanan kesehatan di rumah sakit atau fasilitas pelayanan dapat tercapai bila tersedia biaya operasional dan pemeliharaan sarana dan alat kesehatan yang memadai dan untuk itu haruslah disusun petunjuk teknis dan Standart Operational Procedure (SOP) tentang pemeliharaan dan optimalisasi pemanfaatan sarana rumah sakit dan alat kesehatan.

Peningkatan efisiensi dan efektifitas tersebut dapat dilakukan dengan beberapa cara antara lain adanya suatu guideline atau Standart Operational Procedure (SOP) dalam pemeliharan dan pemanfaatan sarana kesehatan dan alat kesehatan, kalibrasi dan pemeliharaan rutin, pelatihan tehnisi dan operator alat, sosialisasi SOP pada seluruh unit pemakai sarana dan alat kesehatan di rumah sakit yang bersangkutan serta tersedianya suku cadang. Perencanaan pengadaan sarana dan alat kesehatan yang matang sesuai kebutuhan baik dari sisi provider maupun konsumen akan meningkatkan pemanfaatan secara optimal.

Penelitian yang dilakukan di Instalasi Farmasi Rumah Sakit Pandan Arang Boyolali, didapatkan hasil belum ada sarana komputer untuk mengakses data-data obat, akibatnya sistem pelaporan obat masih agak lama karena dikerjakan secara manual. Terdapat alat-alat elektronika yang tidak difungsikan seperti timbangan listrik, alat pencampur larutan. Dari hasil pengamatan, alat tersebut tidak 
digunakan karena kasus resep obat yang ditimbang dan pencampuran larutan sangat jarang. ${ }^{7}$

\section{d. Faktor Tenaga Manusia di Gudang Instalasi Farmasi Rumah Sakit}

Gudang Instalasi Farmasi memiliki 6 (orang) tenaga gudang. Latar belakang pendidikan tenaga gudang yaitu 1 (satu) orang Apoteker sebagai Kepala Gudang, 2 (dua) orang Asisten Apoteker sebagai tenaga administrasi dan 3 (tiga) orang dengan latar belakang pendidikan bukan dari sekolah kefarmasian sebagai tenaga umum. Pembagian tugas di Gudang Instalasi Farmasi terdiri dari 2 shift, yaitu pagi pukul 07.00 WIB-14.00 WIB, dan siang pukul 10.00 WIB-17.00 WIB.

Setiap petugas di Gudang Instalasi Farmasi RS PKU Muhammadiyah Yogyakarta Unit I hampir dapat mengerjakan seluruh kegiatan di gudang, yaitu mulai dari penerimaan obat, pengecekan, pengarsipan, dan penyimpanan obat.

Kesesuaian antara tenaga manusia di Gudang Instalasi Farmasi RS PKU Muhammadiyah Yogyakarta Unit I dengan Standar Pelayanan Farmasi di Rumah Sakit ${ }^{8}$ adalah sebagai berikut:

Tabel 4. Kesesuaian antara Tenaga Manusia di Gudang Instalasi Farmasi RS PKU Muhammadiyah Yogyakarta Unit I dengan Standar Pelayanan Farmasi di Rumah Sakit ${ }^{8}$

\begin{tabular}{lcc}
$\begin{array}{c}\text { Standar Pelayanan Farmasi } \\
\text { di Rumah Sakit }\end{array}$ & $\begin{array}{l}\text { Pelaksanaan di Gudang Instalasi Farmasi } \\
\text { RS PKU Muhammadiyah Yogyakarta Unit I }\end{array}$ \\
\hline Apoteker & Ada & Tidak \\
\hline Sarjana Farmasi & $\sqrt{ }$ \\
\hline Asisten Apoteker (AMF, SMF) & $\sqrt{ }$ \\
\hline
\end{tabular}

Tenaga manusia di Gudang Instalasi Farmasi RS PKU Muhammadiyah Unit I sudah sesuai dengan standar minimal dari Standar Pelayanan Farmasi Rumah Sakit, karena berdasarkan jenis ketenagaan, Gudang Instalasi Farmasi RS PKU Muhammadiyah Yogyakarta Unit I sudah memiliki Apoteker/Sarjana Farmasi dan Asisten Apoteker (AMF dan SMF).

Hambatan yang berkaitan dengan tenaga manusia di Gudang Instalasi Farmasi RS PKU Muhammadiyah Yogyakarta Unit I adalah:

1) Petugas yang berasal dari sekolah umum kurang memiliki pengetahuan mengenai kefarmasian.

2) Jumlah petugas yang kurang menyebabkan petugas gudang merangkap tugas.

Hambatan dari aspek tenaga manusia di Gudang Instalasi Farmasi RS PKU Muhammadiyah Yogyakarta Unit I dapat diatasi dengan cara:

1) Diadakan pelatihan/kursus/sekolah mengenai standar kompetensi yang dipakai di gudang.

2) Membuat SOP (standar operating procedure) bagi tenaga gudang.

3) Pengukuran kepatuhan akan SOP.

4) Melakukan review SOP.

5) Melakukan Analisis Kebutuhan Tenaga gudang.

Berdasarkan Standar Pelayanan Farmasi di Rumah Sakit ${ }^{8}$, Personalia Pelayanan Farmasi adalah sumber daya manusia yang melakukan pekerjaan kefarmasian di rumah sakit yang termasuk dalam Rumah Sakit bagan organisasi rumah sakit dengan persyaratan: Terdaftar di Departeman Kesehatan, Terdaftar di Asosiasi Profesi, Mempunyai izin kerja, Mempunyai SK penempatan. 
Analisa Kebutuhan Tenaga :

a. Jenis Ketenagaan

1) Untuk pekerjaan kefarmasian dibutuhkan tenaga:

a) Apoteker

b) Sarjana Farmasi

c) Asisten Apoteker (AMF, SMF)

2) Untuk pekerjaan administrasi dibutuhkan tenaga:

a) Operator Komputer /Teknisi yang memahami kefarmasian

b) Tenaga Administrasi

c) Pembantu Pelaksana

b. Beban Kerja

Dalam perhitungan beban kerja perlu diperhatikan faktor-faktor yang berpengaruh pada kegiatan yang dilakukan, yaitu :

1) Kapasitas tempat tidur dan BOR.

2) Jumlah resep atau formulir per hari.

3) Volume perbekalan farmasi.

4) Idealnya 30 tempat tidur $=1$ Apoteker (untuk pelayanan kefarmasian).

c. Pendidikan

Untuk menghasilkan mutu pelayanan yang baik, dalam penentuan kebutuhan tenaga harus dipertimbangkan :

1) Kualifikasi pendidikan disesuaikan dengan jenis pelayanan/tugas fungsi.

2) Penambahan pengetahuan disesuaikan dengan tanggung jawab.

3) Peningkatan keterampilan disesuaikan dengan tugas.

d. Waktu Pelayanan

1) Pelayanan 3 shift (24 jam).

2) Pelayanan 2 shift.

3) Pelayanan 1 shift.

Standar kompetensi pelayanan kefarmasian meliputi kemampuan memberikan pelayanan farmakoterapi kepada penderita baik secara lisan maupun tertulis, advokasi kepada penderita atau masyarakat yang ingin melakukan swamedikasi, menyediakan informasi obat dan promosi cara hidup sehat, memberikan konsultasi obat, membuat formulasi sediaan khusus yang mendukung proses terapi, melakukan monitoring efek samping obat, evaluasi terhadap penggunaan obat yang rasional. Sedangkan kompetensi komunikasi farmasi meliputi kemampuan menciptakan hubungan professionalantara farmasis dengan pasien dan keluarga, antara farmasis dengan tenaga kesehatan lain, maupun sesama farmasis berdasarkan saling menghormati dan mengakui kemampuan profesi demi tegaknya martabat profesi. ${ }^{3}$

Kompetensi penting yang harus dimiliki apoteker dalam bidang pengelolaan obat meliputi kemampuan merancang, membuat, melakukan pengelolaan obat di apotek yang efektif dan efesien. Penjabaran dari kompetensi tersebut adalah dengan melakukan seleksi, perencanaan, penganggaran, pengadaan, produksi, penyimpanan, pengamanan persediaan, perancangan dan melakukan dispensing serta evaluasi penggunaan obat dalam rangka pelayanan kepada pasien yang terintegrasi dalam asuhan kefarmasian dan jaminan mutu pelayanan. ${ }^{3}$

Dalam rangka menangani SDM di rumah sakit diperlukan empat komponen penting, yaitu: 1) pengembangan SDM diantaranya pengembangan karir, pendidikan berkelanjutan, peningkatan kemampuan, proses orientasi, dan program 
pembinaan supervisor, 2) pemanfaatan SDM diantaranya penyusunan staf, penerapan hadiah, penilaian kerja, hubungan antar-karyawan, grievans sistem, program yang bermanfaat, pengganjian, penerimaan pegawai, administrasi, 3) rekayasa SDM diantaranya rekayasa industri, pengembangan organisasi, perencanaan tenaga kerja, 4) pengembangan potensi SDM diantaranya analisis potensial, penyesuaian jabatan, wirausaha, penelitian, tim kreatif. $^{3}$

Penelitian yang dilakukan di Instalasi Farmasi Rumah Sakit Pandan Arang Boyolali, didapatkan hasil bahwa karyawan Instalasi Farmasi berjumlah 13 orang yang terdiri dari 1 orang Apoteker, 6 orang Asisten Apoteker, 1 orang Analis Farmasi, dan 5 orang lulusan sekolah umum. Terdapat pembagian tugas dari masing-masing individu dalam kelompok maupun uraian tugas masing-masing individu. Mereka saling membantu bila pekerjaan utama mereka selesai. ${ }^{7}$

\section{SIMPULAN DAN SARAN}

\section{a. Simpulan}

1) Faktor sistem penyimpanan obat di Gudang Instalasi Farmasi RS PKU Muhammadiyah Yogyakarta Unit I tidak sesuai dengan standar Seto, yaitu penggolongan obat tidak berdasarkan kelas terapi/khasiat obat. Hal tersebut dikarenakan tidak semua petugas gudang memiliki latar belakang pendidikan kefarmasian Petugas yang berasal dari sekolah umum akan kesulitan dalam menghapalkan nama-nama obat berdasarkan kelas terapi/khasiat obat, sehingga dikhawatirkan proses penyimpanan akan berlangsung lebih lama.

2) Faktor gedung dan ruangan di Gudang Instalasi Farmasi RS PKU Muhammadiyah Yogyakarta Unit I sudah sesuai dengan Standar Pelayanan Farmasi di Rumah Sakit.

3) Faktor peralatan di Gudang Instalasi Farmasi RS PKU Muhammadiyah Yogyakarta Unit I tidak sesuai dengan Standar Pelayanan Farmasi di Rumah Sakit, yaitu tidak terdapat alarm yang digunakan untuk mendeteksi pencurian. Hal tersebut dikarenakan di bagian dalam rumah sakit sudah memiliki alarm.

4) Faktor tenaga manusia di Gudang Instalasi Farmasi RS PKU Muhammadiyah Yogyakarta Unit I sudah sesuai dengan Standar Pelayanan Farmasi di Rumah Sakit

\section{b. Saran}

1) Rumah sakit membentuk Clinical Leader, yaitu membentuk suatu perkumpulan yang terdiri dari para dokter yang dipimpin oleh para dokter spesialis yang profesional untuk merumuskan suatu standar obat/formularium untuk penyakit yang sedang trend saat ini yang kemudian direkomendasikan ke PFT (Panitia Farmasi dan Terapi) untuk dikembangkan menjadi sebuah formularium. Selain itu, PFT menetapkan program dan prosedur yang membantu memastikan terapi obat yang aman dan bermanfaat. Hal tersebut untuk mengatasi pola peresepan obat oleh dokter yang berubah-ubah, dimana hal tersebut menjadi hambatan dari aspek sistem penyimpanan obat di Gudang Instalasi Farmasi RS PKU Muhammadiyah Yogyakarta Unit I.

2) Membuat satelit gudang farmasi di setiap bangsal perawatan dengan metode Computerize Inventory, yaitu lemari inventory/logistik yang dilengkapi dengan sistem komputerisasi, menggunakan password yang dapat diakses tiap satelit di bangsal perawatan untuk mempermudah permintaan dan pengiriman obat antara gudang utama dengan bangsal perawatan, hal tersebut untuk mengatasi jarak gudang yang terlalu jauh dari Pelayanan Rawat Inap dan luas gudang yang kurang, dimana hal tersebut menjadi hambatan dari aspek gedung dan ruangan Gudang Instalasi Farmasi RS PKU Muhammadiyah Yogyakarta Unit I. 
3) Mengupayakan pengadaan peralatan yang belum dimiliki Gudang Instalasi Farmasi RS PKU Muhammadiyah Yogyakarta Unit I, seperti alarm, timbangan gram dan milligram, alat pencungkil/pembuka peti, dan kartu pemeliharaan yang dipasang pada peralatan penunjang farmasi, dimana hal tersebut menjadi hambatan dari aspek peralatan di Gudang Instalasi Farmasi RS PKU Muhammadiyah Yogyakarta Unit I. Selain itu diperlukan pemeliharaan peralatan penunjang farmasi secara teratur yang dilakukan oleh petugas gudang maupun petugas pemeliharaan untuk mengurangi resiko terjadinya kerusakan.

4) Dilakukan Analisis Kebutuhan Tenaga untuk mengetahui berapa jumlah tenaga manusia yang dibutuhkan, serta CPD (Continuing Professional Development), yaitu membangun kualitas sumber daya manusia secara berkelanjutan melalui program pelatihan, kursus, maupun sekolah bagi petugas gudang untuk mengatasi keterbatasan pengetahuan yang dimiliki petugas gudang, dimana hal tersebut menjadi hambatan dari aspek tenaga manusia di Gudang Instalasi Farmasi RS PKU Muhammadiyah Yogyakarta Unit I.

5) Bagi peneliti lain diharapkan untuk dapat melanjutkan penelitian yang sejenis atau berhubungan dengan penyimpanan obat secara mendalam dengan menambah variabel serta literatur yang dapat dijadikan referensi serta acuan untuk penelitian yang selanjutnya.

\section{DAFTAR PUSTAKA}

1. Aditama, T. Y., Manajemen Administrasi Rumah Sakit, Edisi Kedua, Universitas Indonesia Press, Jakarta. 2003

2. Siregar, Farmasi Rumah Sakit; Teori dan Penerapan, EGC, Jakarta. 2004

3. Damanik, C., Analisis Fungsi-Fungsi Pengelolaan Obat Rumah Sakit Umum di Propinsi Bali, Tesis, Pascasarjana, Universitas Gadjah Mada, Yogyakarta. 2000

4. Quick, J. D., Management Drug Supply : Management Science for Health, Boston. 2006

5. Seto, S., Manajemen Farmasi, Edisi kedua, Airlangga University Press, Surabaya. 2008

6. Harianto, Kurnia, R., Siregar, S., "Hubungan Antara Kualifikasi Dokter dengan Kerasionalan Penulisan Resep Obat Oral Kardiovaskuler Pasien Dewasa Ditinjau dari Sudut Interaksi Obat (Studi Kasus di Apotek "X" Jakarta Timur)", Joumal IImu Kefarmasian, 3 (2): 66-77. 2006

7. Sarmini, Analisis Terhadap Faktor Keberhasilan Manajemen Obat di Instalasi Farmasi Rumah Sakit Pandan Arang Boyolali, Tesis, Pascasarjana, Universitas Gadjah Mada Yogyakarta. 1998 